\title{
Ethanolic extract of Passiflora edulis Sims leaves inhibits protein glycation and restores the oxidative burst in diabetic rat macrophages after Candida albicans exposure
}

\author{
Carolina Fernandes Ribas Martins', Bruno César Corrêa Salles ${ }^{1}$, Maisa Ribeiro Pereira Lima

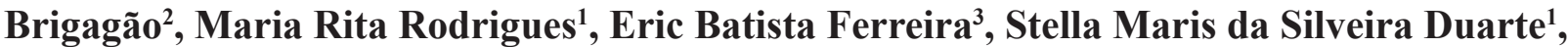 \\ Fernanda Borges de Araujo Paula, ${ }^{1, *}$
}

\begin{abstract}
${ }^{1}$ Faculty of Pharmaceutical Sciences, Departament of Clinical and Toxicology Analysis, Federal University of Alfenas, MG, Brazil, ${ }^{2}$ Institute of Biomedical Sciences, Department of Biochemistry, Federal University of Alfenas, MG, Brazil, ${ }^{3}$ Insitute of Exact Sciences, Federal University of Alfenas, Federal University of Alfenas, MG, Brazil
\end{abstract}

\begin{abstract}
This study was conducted to evaluate the effects of the ethanolic extract of Passiflora edulis leaves on blood glucose, protein glycation, NADPH oxidase activity and macrophage phagocytic capacity after Candida albicans exposure in diabetic rats. The Passiflora edulis Sims leaves were dried to $40^{\circ} \mathrm{C}$, powdered, extracted by maceration in 70\% ethanol, evaporated under reduced pressure and lyophilised. The biochemical tests performed were total phenolic content (TP) as determined by the Folin-Ciocalteu assay, trapping potential DPPH assay and total iron-reducing potential. Diabetes was induced by alloxan injection. Protein glycation was determined by AGE and fructosamine serum concentrations. Extracttreated diabetic animals demonstrated lower fructosamine concentrations compared with the diabetic group. Our results suggest that ethanolic Passiflora edulis Sims leaf extraction may have beneficial effects on diabetes and may improve glycaemic control in diabetic rats.
\end{abstract}

Uniterms: Passiflora edulis Sims/pharmacognosy. Passiflora edulis Sims/ethanolic extract/effects. Blood glucose. Protein glycation. Reactive oxygen species. Diabetes/treatment/experimental study. Medicinal plants.

O objetivo deste estudo foi avaliar os efeitos do extrato etanólico de folhas de Passiflora edulis sobre os níveis de glicose sanguínea, glicação protéica, produção de espécies reativas de oxigênio (ERO) e capacidade fagocítica de macrófagos de ratos diabéticos. As folhas de Passiflora edulis Sims foram secas a $40{ }^{\circ} \mathrm{C}$, trituradas e o extrato preparado por maceração em solução hidroetanólica $70 \%$ (v/v) etanol foi evaporado sob pressão reduzida e liofilizado. Os testes químicos realizados demonstraram que além da presença de compostos fenólicos, determinada pelo método de Folin-Ciocalteu, o extrato apresentou potencial sequestrante de radicais DPPH e redutor de ferro. Nos animais diabéticos foi observado aumento na glicação protéica, avaliada pela concentração de frutosaminas e de produtos de glicação avançada (AGE), e redução na produção de ERO por macrófagos frente à Candida albicans, quando comparados ao grupo controle. O tratamento dos animais diabéticos com o extrato reduziu as concentrações de frutosaminas e manteve a produção de ERO em níveis semelhantes aos observados no grupo controle. Nossos resultados sugerem que o extrato etanólico de folhas de Passiflora edulis Sims pode apresentar efeitos benéficos sobre o diabetes e melhorar o controle glicêmico em ratos diabéticos.

Unitermos: Passiflora edulis Sims/farmacognosia. Passiflora edulis Sims/extrato etanólico/efeitos. Glicose sanguínea. Glicação protéica. Espécies reativas de oxigênio. Diabetes/tratamento/estudo experimental. Plantas medicinais.

\footnotetext{
*Correspondence: F. B. de Araujo Paula. Departamento de Análises Clínicas. Faculdade de Ciências Farmacêuticas. Universidade Federal de Alfenas. Rua Gabriel Monteiro da Silva, 700. Centro, 37130-000 - Alfenas - MG, Brasil. E-mail addresses: fbapaula@yahoo.com.br; fernanda.paula@unifal-mg.edu.br
} 


\section{INTRODUCTION}

Diabetes mellitus is a serious public health problem due to the high incidence, morbidity and mortality rates that are mainly caused by the complications of this chronic disease (Shaw, Sicree, Zimmet, 2010).

Among these complications, diabetic individuals usually present with increased susceptibility to infections, which causes health problems. Studies have demonstrated that approximately $20 \%$ of septicaemia patients are diabetic. Furthermore, the high frequency of infection may aggravate a pre-existing medical condition (Koh et al., 2012).

Many factors contribute to an increased susceptibility to infections; however, deficiency in innate immune function is the major cause of such manifestations (Geerlings, Hoepelman, 1999).

Some studies have suggested that increased susceptibility to infections might be associated with alterations in immune function and the phagocyte inflammatory response (chemotaxis, phagocytosis and killing), which could reduce the phagocytic and microbicidal capacity of these cells (Panneerselvam, Govindasamy, 2003; Ferreira et al., 2012; McNelis, Olefsky, 2014).

Alterations in the production of reactive oxygen species (ROS) by phagocytes have been implicated as a cause of dysfunction in diabetes; however, the data describing the influence of diabetes on mononuclear cell NADPH oxidase activity are still divergent (Banerjee, Sharma, 2012).

The increase in advanced glycation end product (AGE) formation because of interactions between glucose and protein molecules may also influence immune function either by binding to immunoglobulins or by interacting with specific receptors (RAGE) that are present on macrophages, which alters proinflammatory cytokine expression (Barbosa, Oliveira, Seara, 2008).

Brazil is the major producer of Passiflora edulis, also known as yellow passion fruit. This fruit has great nutritional value, and its leaves have been widely used in traditional medicine with beneficial effects in various diseases. P. edulis leaf extract has sedating, anxiolytic, anti-inflammatory and antibacterial properties (Dhawan Dhawan, Sharma, 2004; Li et al., 2011).

Experimental studies have suggested that leaf extracts of different Passiflora species may have hypoglycaemic, antioxidant and anti-glycation properties. These properties have been attributed mainly to the presence of phenolic compounds, among which the flavonoid C-glycosides isoorientin, orientin, vitexin, apigenin, and others stand out. However, many of these studies were performed in vitro and were simplified to be extrapolated to the body. Furthermore, scientific information regarding the use of passion fruit leaves in diabetes treatment is still controversial (Doyama et al., 2005; Rudnicki et al, 2007).

Thus, the aim of the present study was to evaluate the effects of the ethanolic extract of Passiflora edulis Sims leaves on blood glucose, protein glycation, NADPH oxidase activity and phagocytic capacity of diabetic rats' macrophages exposed to Candida albicans.

\section{MATERIAL AND METHODS}

\section{Obtaining passion fruit leaf samples}

The passion fruit leaf samples were classified as Passiflora edulis Sims species. The leaves were collected from passion fruit plant cultivated in sandy soil with organic matter, in March 2012, in the city of Alfenas, Minas Gerais, Brazil, which has the following GPS coordinates of latitude $21^{\circ} 27^{\prime} 33^{\prime} \mathrm{S}$, longitude $46^{\circ} 01^{\prime} 59^{\prime}$ $\mathrm{W}$ to $789 \mathrm{~m}$. The voucher specimen of this sample was preserved in our department with reference number 22356, which was obtained by Federal University of Lavras, Department of Biology, ESAL herbarium.

\section{Passiflora edulis Sims lead ethanolic extract preparation}

The Passiflora edulis Sims leaves were dried at $40{ }^{\circ} \mathrm{C}$, powdered in an industrial blender, extracted by $70 \%$ ethanol maceration, evaporated under reduced pressure and lyophilised (Rudinicki et al., 2007).

\section{Total phenolic content determination}

Total phenolic content (TP) was determined using the Folin-Ciocalteu assay (Singleton, Orthofer, Lamunela, 1999). Test sample TP content was standardised against gallic acid and expressed as "mg gallic acid equivalents/100 g extract (GAE)". Each determination was performed in triplicate.

\section{Trapping Potential DPPH assay}

This assay has been widely used to evaluate the antioxidant activity of vegetables extracts in vitro, based on electron-transfer. The 2,2'-diphenyl-1-picrylhydrazyl (DPPH) is a stable free radical which may be reduced in the presence of antioxidant substances, giving rise to the reduced form with the loss of this violet colour (Molyneux, 2004). 
The measurement of DPPH radical scavenging activity was performed according to the methodology described by Dudonné et al. (2009). The different concentrations of Passiflora edulis ethanolic extract samples $(0.125,0.5,1.0,5.0,10.0,15.0$ or $20.0 \mathrm{mg} /$ $\mathrm{mL})$ were reacted with the DPPH in a methanolic solution $(0.02 \%, \mathrm{w} / \mathrm{v})$. The absorbance recorded at 517 $\mathrm{nm}$ against an aliquot blank. DPPH radical-scavenging activity of the Passiflora edulis leaf ethanolic extract was expressed in percentage compared with the control that only contained $0.02 \%$ DPPH solution; these data were compared to a standard curve that was made with BHT ethanolic solution at the same concentration as the Passiflora edulis ethanolic extract. Each determination was performed in triplicate.

\section{Total iron-reducing potential}

The iron-reducing potential of the Passiflora edulis leaf ethanolic extract was determined by adding different Passiflora edulis extract concentrations $(0.5,10,20,40$, 80,120 or $160 \mathrm{mg} / \mathrm{mL}$ ) into phosphate buffer with $1 \%$ potassium ferricyanide, which was placed in a water bath at $50^{\circ} \mathrm{C}$ for 30 minutes. Trichloroacetic acid $(10 \%)$ was then added, and the solution was centrifuged at 3,000 rpm for 10 minutes. After centrifugation, $0.1 \%$ ferric chloride was added and the solution was vortexed. The absorbance was read at $700 \mathrm{~nm}$ in a spectrophotometer (Biospectro SP - 220). The iron-reducing properties of the test sample were standardised against butylated hydroxytoluene (BHT), and the results were expressed as a percentage compared with 1\% BHT (Dudonné et al., 2009).

\section{Animals}

The study was conducted in accordance with the ethical principles for animal experimentation that have been adopted by the Brazilian College of Animal Experimentation, and the study was approved by the ethics committee on animal research at the Federal University of Alfenas. In total, 24 adult male Wistar rats (Rattus norvegicus) weighing $350 \pm 25 \mathrm{~g}$ that were obtained from the Unifal-MG vivarium were used in this study. The rats were housed in a temperature-controlled room on a 12 $\mathrm{h}$ light/dark schedule with food and water available ad libitum.

\section{Alloxan-induced diabetic rats}

Alloxan ( $2 \%$ solution) was administered intraperitoneally (150 mg. $\left.\mathrm{kg}^{-1}\right)$ (Etuk, 2010). In this study, diabetic rats were defined as those with glycaemia over $250{\mathrm{mg} . \mathrm{dl}^{-1}}^{\text {after }} 7$ days of alloxan injection. Blood glucose was monitored using test strips with blood taken from the tail. At the time of sacrifice, blood was collected by cardiac puncture, and blood glucose levels were measured using an enzymatic method based on the Trinder reaction.

\section{Animal experimental protocol}

The animals were allocated into 4 groups of 6 animals: Control (C) - non-diabetic animals that were not treated with ethanolic extract; Diabetics (D) - alloxantreated animals; Extract (E) - non-diabetic animals treated with Passiflora edulis leaf ethanolic extract; and Diabetic Extract (DE) - alloxan-treated animals also treated with Passiflora edulis leaf ethanolic extract. The ethanolic extract was diluted in water and administered to the animals by gavage for 8 weeks, after the induction of diabetes. The dose administered was $200 \mathrm{mg}$ dried ethanolic extract per kilogram of body weight per day. The final volume administered to each animal was 0.5 $\mathrm{mL}$. The control group received $0.5 \mathrm{~mL}$ water (Dhanabal et al., 2004). After 55 days of treatment with the extract and water, the animals received 3\% sodium caseinate intraperitoneally for macrophage recruitment. The animals were anaesthetised on the $57^{\text {th }}$ day, and blood was collected by cardiac puncture after a 12 -hour fast. The animals were euthanised, and the macrophages were isolated from the peritoneal fluid with the addition of sterile $4{ }^{\circ} \mathrm{C}$ phosphate buffer, $\mathrm{pH} 7.4$.

\section{Obtaining serum and whole blood}

To obtain serum, the second aliquot of blood was distributed into siliconised glass tubes (without additive) and maintained at rest until blood clotting was complete. The samples were centrifuged at $1500 \times \mathrm{g}$ for 10 minutes and stored at $-80^{\circ} \mathrm{C}$. These samples were used for blood glucose evaluation and for AGE dosage (Advanced glycation end-product).

\section{Cell suspension preparation}

The cell suspension was obtained by peritoneal lavage and centrifuged at $2000 \mathrm{~g}$ for 15 minutes. The supernatant was resuspended in PBS plus glucose and kept on ice until the assay. These cell samples were used to evaluate reactive oxygen species production as well as the phagocytic and fungicidal ability of the macrophage when exposed to yeast solution. Cell viability was evaluated by trypan blue exclusion $(0.1 \%)$. The cell number obtained from the peritoneal cavity was determined using a 
Newbauer's chamber, the different cell types present were evaluated by morphological analysis, subjected to cytocentrifugation and stained with May-GrunwaldGiemsa (Daniel et al., 1971).

\section{Yeast preparation}

Candida albicans yeast (ATCC 69548) was opsonised at a 1:5 ratio in diabetic or non-diabetic rat serum in 0.01 mol. $1^{-1}$ phosphate buffer, $\mathrm{pH} 7.4$, containing 0.15 mol. $1^{-1} \mathrm{NaCl}$ (PBS) for 30 minutes at $37{ }^{\circ} \mathrm{C}$ with $50 \mathrm{rpm}$ orbital shaking. Viability was determined by $0.05 \%$ methylene blue exclusion $(99.9 \%$ ), and the number of Candida albicans was determined in a Neubauer's chamber.

\section{Phagocytic and fungicide capacity assessment}

Macrophages $\left(3.10^{6}\right.$ cell $\left.\mathrm{s} / \mathrm{mL}\right)$ were incubated in sterile plastic tubes (to avoid cell adherence) at $37{ }^{\circ} \mathrm{C}$ with opsonised C. albicans $\left(3.10^{7}\right.$ cells $\left./ \mathrm{mL}\right)$. After 30,60 , and $90 \mathrm{~min}$ incubation, a $50 \mu 1$ aliquot of this suspension was adhered to glass cover slips by cytocentrifugation (Sorocito FANEM). After centrifugation, cover slips were stained with Wright and May-Giemsa stains. The percentage of phagocytic cells was determined by counting the percentage of macrophages that had phagocytosed one or more C. albicans particles. The percentage of phagocytic cells and the number of yeast cells attached per 100 randomly chosen macrophages were counted by examining at least 200 macrophages per preparation (Ferreira et al., 2012).

\section{Luminol-amplified chemiluminescence}

For this assay, macrophages $\left(1.10^{6}\right.$ per millilitre $)$ were activated with $C$. albicans $\left(1.10^{7}\right.$ per millilitre $)$ in a reaction mixture containing luminol $\left(1 \mathrm{mmol} . \mathrm{L}^{-1}\right)$ and PBS, $\mathrm{pH}$ 7.4. Chemiluminescence intensity was followed in a Geomax luminometer W 20/20, and the final volumes were $0.3 \mathrm{~mL}$. Chemiluminescence is expressed as relative light units per second (RLU/s). The reaction was followed for $60 \mathrm{~min}$. All of the measurements were made at $37^{\circ} \mathrm{C}$. As controls, the reactions were carried out without cells, without luminol or without C. albicans.

\section{Assessment of protein glycation}

Protein glycation was assessed by determining AGE and fructosamine serum concentration. Fructosamine concentration was determined using the 2-point colorimetric kinetic method with a commercial brand
Analisa Gold test. The absorbance was read at $530 \mathrm{~nm}$ in a semi-automatic BioPlus. AGEs were quantified by measuring fluorescence, as described by Zilin et al. (2001). Previously, we determined serum protein concentration using the Biuret method. Afterwards, AGEs were quantified by adding $70 \mu \mathrm{L}$ serum in $330 \mu \mathrm{L}$ chloroform in plastic tubes. Proteins were then precipitated by adding $1.6 \mathrm{~mL} 0.15 \mathrm{M}$ trichloroacetic acid followed by vortexing and centrifugation at $12000 \times \mathrm{g}$ for 15 minutes. The fluorescence was read at wavelengths of $350 \mathrm{~nm}$ (excitation) and $440 \mathrm{~nm}$ (emission) with a gap of $5 \mathrm{~nm}$. The results were expressed as arbitrary units divided by the serum protein concentration (AU/g protein) (Zilin et al., 2001).

\section{Statistical Analysis}

The results were expressed as the mean \pm standard deviation; they were also submitted to one-way analysis of variance and compared using the Scott-Knott test at $5 \%$ significance.

\section{RESULTS AND DISCUSSION}

For the preliminary evaluation of the antioxidant properties of Passiflora edulis leaf ethanolic extract, some tests were performed to evaluate their reducing potential and free radical scavenging capacity. The FRAP method is based on electron transfer from compounds present in the extract to iron ions, while the DPPH method assesses the ability of the extract to donate hydrogen atoms to DPPH and stabilise it. The results demonstrated that the P. edulis leaf ethanolic extract had antioxidant activity in vitro and was able to donate hydrogen atoms to DPPH and transfer electrons to iron ions (Figures 1 and 2). $\mathrm{EC}_{50}$ values observed for the two methods used in this study, and our results, demonstrate that the in vitro antioxidant potential presented by the $P$. edulis ethanolic extract can be attributed to the ability of scavenging free radicals rather than the FRAP method. This difference could be attributed to the ability of the chemical compounds present in the extract to donate hydrogen or reduce iron ions. These results reinforce the importance of using two or more techniques for antioxidant activity evaluation as recommended by Wootton-Beard, Moran, Ryan (2011).

The results represent the average \pm standard deviation performed in triplicate.

Among the compounds with the ability to donate hydrogen atoms or have reductive action, the phenolic compounds have been the subject of great interest in the scientific literature because of their effects on 


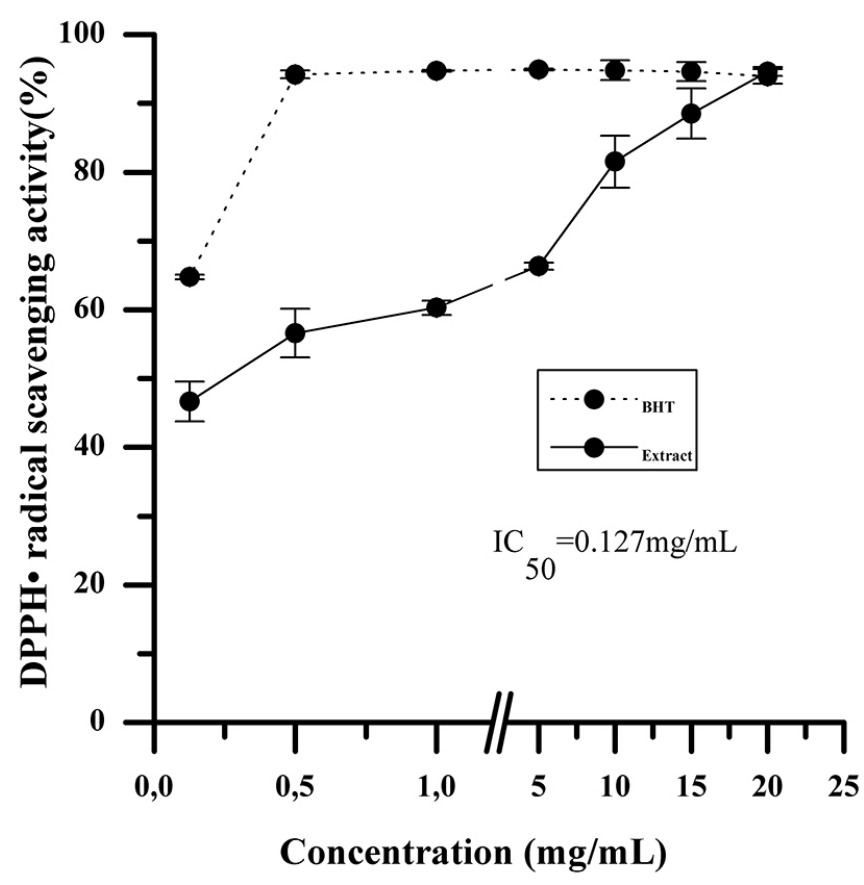

FIGURE 1 - Trapping Potential DPPH Assay of the Passiflora edulis leaf ethanolic extract compared with the standard BHT.

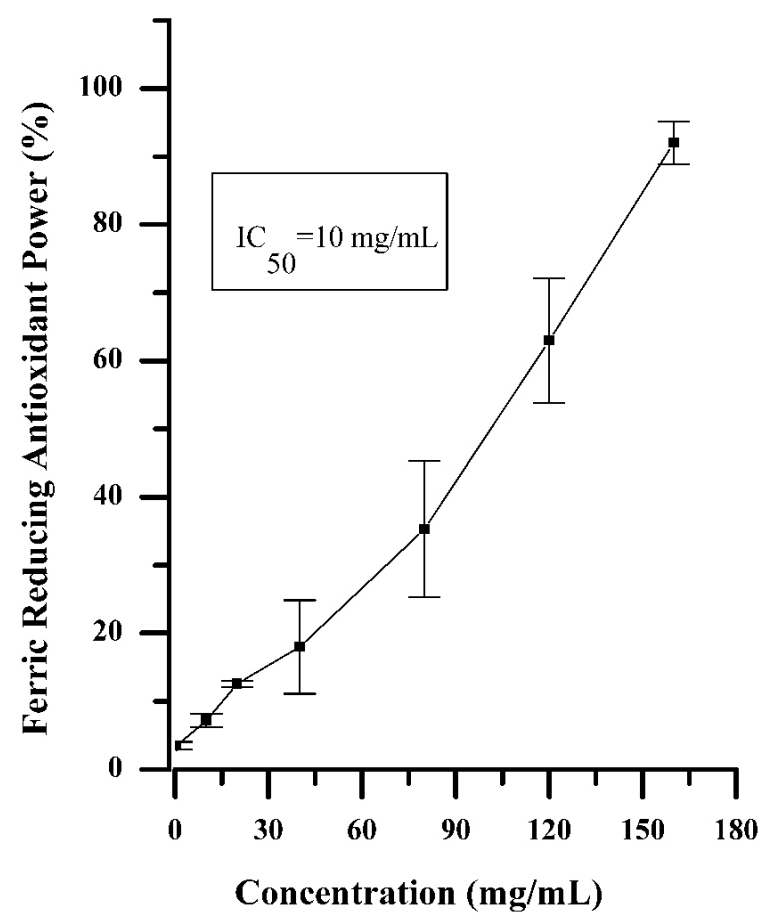

FIGURE 2 - Total iron-reducing power assay of the Passiflora edulis leaf ethanolic extract. The results represent the average \pm standard deviation performed in triplicate.

human health, such as oxidative stress inhibition and the prevention or treatment of diabetes mellitus, inflammation and infectious processes (Rodrigo, Miranda, Vergara,
2011). Thus, as a preliminary analysis of the $P$. edulis ethanolic extract chemical composition, the total phenolic content was determined for this extract.

The results suggest that the extract has phenolic compounds. The literature has demonstrated the presence of phenolic compounds in different Passiflora species, mostly in the form of flavonoid C-glycosides such as isoorientin, which is one of the main flavonoids present in passion fruit juice. However, data on polyphenol concentration in P. edulis leaf extracts are still controversial because there is great variation in this species, the method of extract preparation and expression of the results ( $\mathrm{Li}$ et al., 2011; Rudnick et al., 2007).

The phenolic content of $P$. edulis $(4.67 \pm 0.115 \mathrm{~g}$ $\mathrm{GAE} / 100 \mathrm{~g}$ extract) observed in the ethanolic extract was similar to the concentrations reported by Oliveira et al. (2009), when passion fruit methanol extract waste was examined. Furthermore, the $P$. edulis ethanolic extract phenolic content was higher than the concentrations that were observed in different studies with other herbal extracts that have potential anti-inflammatory and hypoglycaemic properties (Caia et al., 2004; Souza et al., 2008).

The association between phenolic content and antioxidant activity have been observed in different studies with medicinal plant extracts, including the genus Passiflora (Caia et al., 2004; Rudnicki et al., 2007; Souza et al., 2008). Caia et al. (2004) evaluated the in vitro antioxidant activity and phenolic content in approximately 112 medicinal plants used in Chinese folk medicine. The authors reported that phenolic compounds were the main components with antioxidant activity in these plants. Furthermore, positive correlations have been observed in different studies between phenolic content and extract antioxidant activity from plants that originated from the Amazon Rainforest with potential anti-inflammatory and hypoglycaemic effects (Souza et al., 2008). Some authors have also reported an association between antioxidant activity and phenolic content in Passifloraceae genus fruit extracts or plant leaves (Oliveira et al., 2009; Rudnick et al., 2007).

Thus, our results suggest that the presence of phenolic compounds in the $P$. edulis ethanolic extract could contribute to the iron reduction power and free radical scavenging that was observed in this study.

Antioxidants from plant extracts have an important role in oxidative processes and also in preventing or treating various diseases including diabetes mellitus (Rodrigo, Miranda, Vergara, 2011). Considering the results obtained from the evaluation of $P$. edulis ethanolic extract antioxidant activity in vitro and several studies 
TABLE I - Effect of $P$. edulis leaf ethanolic extract on glucose levels, fructosamine concentrations and advanced glycation endproduct (AGE) quantification in non-diabetic and diabetic animals

\begin{tabular}{|c|c|c|c|c|c|}
\hline \multirow[t]{2}{*}{ Experimental group } & \multirow{2}{*}{$\begin{array}{l}\text { Glycaemia } \\
\text { (mg/dl) }\end{array}$} & \multirow{2}{*}{$\begin{array}{l}\text { Fructosamines } \\
\qquad(\mathrm{mmol} / \mathrm{L})\end{array}$} & \multirow{2}{*}{$\begin{array}{c}\text { AGE } \\
\text { (AU/g prot) }\end{array}$} & \multicolumn{2}{|c|}{ Body weight (g) } \\
\hline & & & & $1^{\text {st }}$ week & $8^{\text {st }}$ week \\
\hline $\mathrm{C}$ & $113,78 \pm 13,52^{\mathrm{a}}$ & $1,63 \pm 0,18^{\mathrm{a}}$ & $0,11 \pm 0,02^{\mathrm{a}}$ & $354,50 \pm 20,87^{\mathrm{a}}$ & $417,00 \pm 17,03^{\mathrm{a}}$ \\
\hline $\mathrm{D}$ & $285,78 \pm 69,35^{\mathrm{b}}$ & $2,38 \pm 0,41^{b}$ & $0,17 \pm 0,06^{\mathrm{b}}$ & $351,00 \pm 19,34^{\mathrm{a}}$ & $264,67 \pm 38,05^{b}$ \\
\hline E & $90,95 \pm 10,57^{\mathrm{a}}$ & $1,61 \pm 0,07^{\mathrm{a}}$ & $0,10 \pm 0,02^{\mathrm{a}}$ & $344,17 \pm 17,05^{\mathrm{a}}$ & $401,83 \pm 22,69^{a}$ \\
\hline $\mathrm{DE}$ & $269,98 \pm 115,58^{\mathrm{a}}$ & $1,85 \pm 0,49^{\mathrm{a}}$ & $0,13 \pm 0,04^{\mathrm{a}}$ & $348,50 \pm 15,75^{\mathrm{a}}$ & $280,66 \pm 36,35^{\mathrm{b}}$ \\
\hline
\end{tabular}

The results represent the average \pm standard deviation of 6-8 determinations per treatment. Different letters in the same column indicate statistical significance, $\mathrm{p}<0.05 . \mathrm{C}=$ control group; $\mathrm{D}=$ diabetic animals; $\mathrm{E}=P$. edulis ethanolic extract-treated non-diabetic animals; $\mathrm{DE}=P$. edulis ethanolic extract-treated diabetic animals.

demonstrating the importance of medicinal plants with antioxidant properties presented by the active principles present in these plants (Rodrigo, Miranda, Vergara, 2011; Rudinicki et al., 2007), this study evaluated the effects of $P$. edulis leaf ethanolic extract ingestion on glycaemic control and serum protein glycation in diabetic rats (Table I).

Several studies have used glycation end product measurement in the diabetic patient serum to assess the risk of disease progression, demonstrating a positive correlation between glycated proteins levels in blood samples and the prevalence of diabetes mellitus-induced chronic complications (Brownlee, 1995; Rondeau, Boundon, 2011).

In this study, alloxan-treated animals demonstrated severe weight loss, hyperglycaemia, elevated serum fructosamines and AGE, demonstrating that the protocol was effective for diabetes induction (Table I). Among the strategies adopted to reduce or maintain glycated blood protein levels within the desirable limits, glycaemic control is undoubtedly the main concern. Ethanolic extract administration failed to induce significant changes in blood glucose and fluorescent AGE serum levels, but fructosamine concentration was significantly lower in the extract-treated diabetic animal serum compared with untreated diabetic animals, demonstrating that the P. edulis ethanolic extract prevented an increase in serum protein glycation in diabetes mellitus.

Fructosamine formation involves an interaction between the nucleophilic group of glucose molecules and the amine group of serum proteins, mainly albumin. Therefore, fructosamine levels reflect glycaemic control during two to three weeks prior to blood collection, while fasting glucose levels reflects momentary glycaemic control. These effects can be attributed to time between extract administration and blood collection (12 hours). Thus, these results suggest that despite the ethanolic extract did not influence fasting glucose levels, it could have reduced the blood glucose level shortly after its administration and contributed to a reduction of the average glycaemic level during the day, which is beneficial for glycaemic control.

The hypoglycaemic effects of $P$. edulis, P. mollisima and $P$. quadrangular leaf alcoholic extracts were observed after oral administration in diabetic mice for a period of 8 days. However, the administration of $P$. alata tea leaves orally for a period of 15 days was not able to reduce blood glucose levels in normoglycaemic rats (Doyama et al., 2005).

Arya et al. (2012) demonstrated that the Centratherum anthelminticum seed methanolic fraction exhibited potential anti-diabetic effects in pancreatic beta cell culture and in streptozotocin-induced diabetic rats. These effects were associated with polyphenols that were identified in the methanolic fraction of the extract. Furthermore, several studies have associated the anti-diabetic effects presented by some medicinal plants to the presence of polyphenols (Rodrigo, Miranda, Vergara, 2011). Therefore, the results observed in this study could be attributed to the presence of phenolic compounds in the P. edulis ethanolic extract, which could consequently contribute to glycaemic control either by increasing insulin sensitivity or by decreasing the intestinal absorption of carbohydrates.

Another way of assessing protein glycation is by determining AGE concentration. These products are formed from Amadori products by means of a complex cascade of reactions, which can take weeks or months to complete. This determination has been adopted to assess protein glycation and long-term glycaemic control (Barbosa, Oliveira, Seara, 2008).

In the present study, an increase in the AGE concentration was observed in the serum of diabetic rats compared with non-diabetic animals (Table I).

In vitro studies have demonstrated that hydroethanolic extracts from $P$. alata leaves inhibited 
AGE formation from albumin and glucose interaction. The authors attributed these effects to the antioxidant activity in the analysed extracts (Rudnicki et al., 2007). Although other mechanisms may be involved in the antiglycation activity of natural and synthetic compounds, the actions of most of these compounds has been linked to their antioxidant properties, particularly the ability to chelate metals and scavenge carbonyl radicals (Edeas et al., 2010). Moreover, many studies have attributed these effects to the presence of phenolic compounds such as flavonoids (Edeas et al., 2010).

However, in the present study, there was no significant difference in the concentration of serum AGE among diabetic animals that were treated or not with the extract (Table I).

Considering that the ethanolic extract of $P$. edulis presented free radical scavenging activity as well as iron-reducing potential and that there was decrease in the serum fructosamine concentration in the extracttreated diabetic animals, the absence of effects on AGE concentration could be attributed to fact of that not all serum AGE have the ability to fluoresce between 370 and $440 \mathrm{~nm}$ (Schleicher et al., 2001). Thus, ethanolic extract treatment may exert its effect only on the non-fluorescent AGE. Our group should perform future experiments to assess the effects of the extract on non-fluorescent AGE concentrations such as that of carboxymethylcysteine (CML), which is largely found in the serum.

Hyperglycaemia can negatively modulate the phagocytic cell response to infectious agents, which could explain the increased susceptibility to infections that is usually noted in diabetic patients (Banerjee, Sharma, 2012; Souza et al., 2007). Moreover, macrophages are central components of the innate immune response to $C$. albicans, and ROS production by these cells is reportedly an important mechanism for their activation and the destruction of these pathogens (Slauch, 2011).

Our results have demonstrated that diabetes mellitus and $P$. edulis ethanolic extract treatment were not able to induce changes in macrophage phagocytic capacity (Figure 3), but ROS production was significantly lower in diabetic rat peritoneal macrophages compared with nondiabetic animals (Figure 4). Furthermore, extract treatment restored macrophage ROS production in diabetic animals.

Phagocytosis occurs after pathogen recognition by macrophages via specific receptors that are present on the cell membrane. During phagocytosis, ROS are generated by NADPH oxidase activation in a process called an oxidative burst. In this process, superoxide anions are produced, and although this molecule presents low microbicide activity, it is required to generate more

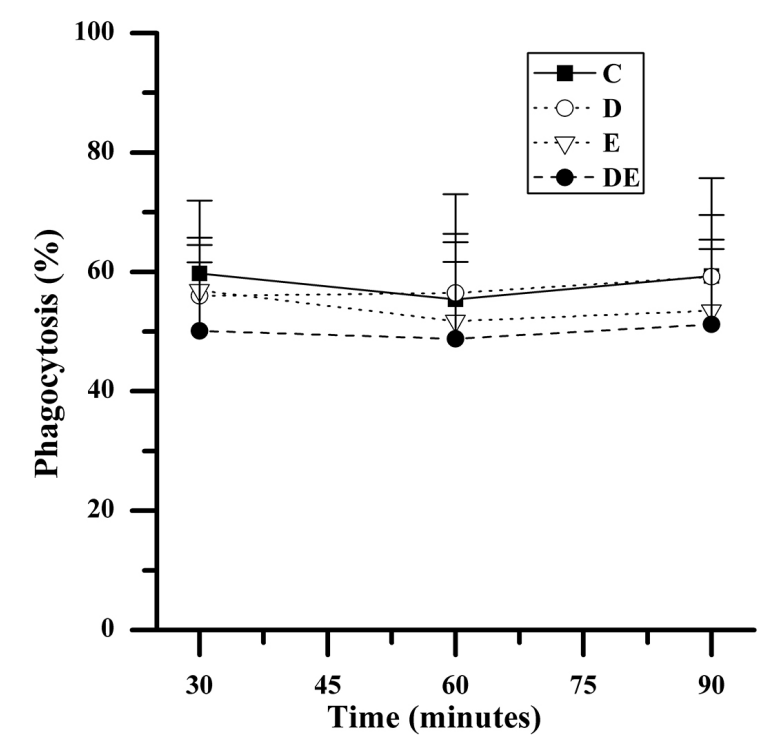

FIGURE 3 - Effect of $P$. edulis leaf ethanolic extract on the ability of diabetic and non-diabetic rat peritoneal macrophages to phagocyte Candida albicans. Macrophages were incubated with opsonised yeast $C$. albicans for $0,30,60,90$ or 120 minutes, and the percentage of macrophages that phagocytised one or more yeast molecules (\% phagocytosis) was determined. The results represent the average \pm standard deviation of 4-5 determinations per treatment. $\mathrm{C}=$ control group; $\mathrm{D}=$ diabetic animals; $\mathrm{E}=$ P. edulis ethanolic extract-treated non-diabetic animals; $\mathrm{DE}=P$. edulis ethanolic extract-treated diabetic animals.

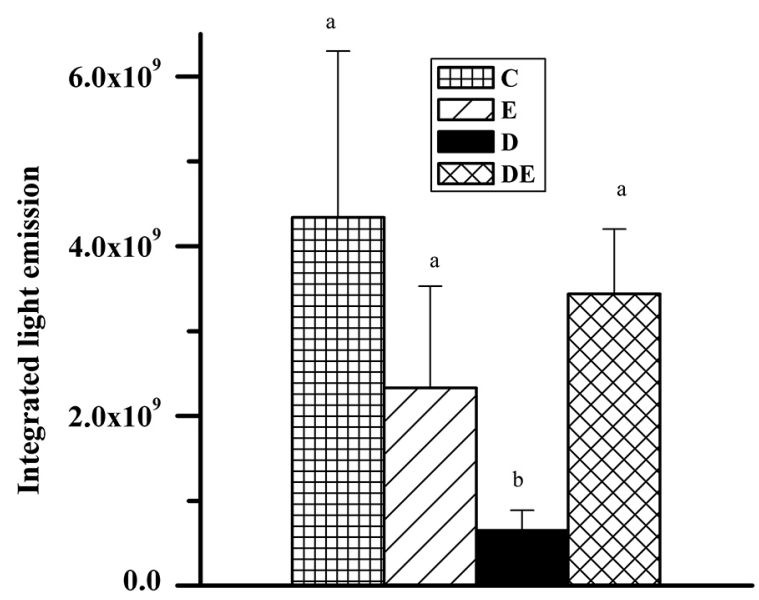

FIGURE 4 - Effect of the Passiflora edulis leaf ethanolic extract on Reactive Oxygen Species (ROS) production in diabetic and non-diabetic rats. The values are represented as the means \pm $\mathrm{SD}$ of the four-five experiments of the integrated light emission area that was obtained for luminol oxidation $\left(1 \mathrm{mmol} . \mathrm{L}^{-1}\right)$ promoted by Candida albicans $\left(1 \times 10^{7}\right.$ cells per test)-stimulated rat peritoneal macrophages $\left(1 \times 10^{6}\right.$ cells per test) from control animals (C), diabetic animals (D), Passiflora edulis ethanolic extract-treated non-diabetic animals (E) and Passiflora edulis ethanolic extract-treated diabetic animals (DE). Different letters indicate statistical significance $(\mathrm{p}<0.05)$. 
potent molecules such as $\mathrm{HOCl}$ (Babior, 2002; Slauch, 2011). When macrophages are activated, the generated ROS can oxidise molecules such as luminol to its excited and unstable intermediates, which can be measured by chemiluminescence (Vilim, Wilhelm, 1999).

Several studies have demonstrated impaired phagocytic cell activity in diabetes mellitus (AlbaLoureiro et al., 2006). However, the results regarding the effects of diabetes mellitus on ROS production in these cells are still divergent. Some authors have observed increased ROS production in phagocytic cells of diabetic animals or humans (Willians et al., 2011); however, Souza et al. (2007) determined that ROS production by lipopolysaccharide (LPS)-stimulated RAW 264.7 macrophages was lower in the presence of high glucose concentrations $(500 \mathrm{mg} / \mathrm{dL})$ when compared with cells that were incubated with normal glucose concentrations (200 mg/dL). Banerjee, Sharma (2012) reported that the NADPH oxidase activity of macrophages that were maintained in different glucose concentrations decreased as glucose concentrations increased. Furthermore, the authors observed an association between increased cell membrane glycation and reduced macrophage NADPH oxidase activity.

Thus, our results suggest that inhibition of the macrophage oxidative burst in diabetic rats could be one of the mechanisms that is responsible for the susceptibility to infections in diabetic patients and the administration of P. edulis ethanolic extract could contribute to preventing this disorder.

Hyperglycaemia can lead to the glycation of proteins that are present in the macrophage membrane including NADPH oxidase subunits, thus compromising its activity. Therefore, the effect of $P$. edulis ethanolic extract treatment on diabetic rat macrophage ROS production could be related to its action on protein glycation, as evidenced by the fructosamine results.

Thus, our results suggest that the ethanolic extract may have beneficial effects on the diabetic state by contributing to glycaemic control and the modulation of macrophage oxidative burst in diabetic rats.

\section{CONCLUSIONS}

The ethanolic extract demonstrated higher phenolic content than the various medicinal plants that are used in folk medicine and demonstrated antioxidant activity in vitro, as evidenced by DPPH radical scavenging capacity and iron-reducing power. Ethanolic extract administration in the animals prevented an increase in diabetic animal serum protein glycation and contributes to maintaining diabetic rat macrophage ROS production at levels that are similar to those of non-diabetic animals.

\section{ACKNOWLEDGMENTS}

The authors thank CAPES and FAPEMIG.

\section{REFERENCES}

ALBA-LOUREIRO, T.C.; HIRABARA, S.M.; MENDONÇA, J.R.; CURI, R.; PITHON-CURI, T.C. Diabetes causes marked changes in function and metabolism of rat neutrophils. J. Endocrinol., v.188, n.2, p.295-303, 2006.

ARYA, A.; LOOI C.Y.; CHEAH, S.C.; MUSTAFA, M.R.; MOHD, M.A. Anti-diabetic effects of Centratherum anthelminticum seeds methanolic fraction on pancreatic cells, b-TC6 and its alleviating role in type 2 diabetic rats. J. Ethnopharmacol., v.144, n.1, p.22-32, 2012.

BABIOR, B.M. The leukocyte NADPH oxidase. Israel Med. Am. J., v.4, p.1023-1024, 2002.

BARBOSA, J.H.; OLIVEIRA, S.L.; SEARA, L.T. O papel dos produtos finais da glicação avançada (AGEs) no desencadeamento das complicações vasculares do diabetes. Arq. Bras. Endocrinol. Metab., v.52, n.6, p.940-950, 2008.

BANERJEE, D.; SHARMA, P. Dual effect of glucose on macrophage NADPH oxidase activity: a possible link between diabetes and tuberculosis. Oxid. Antioxid. Med. Sci., v.1, n.1, p.91-96, 2012.

BROWNLEE, M. The pathological implications of protein glycation. Clin. Invest. Med., v.18, p.275-281, 1995.

CAIA, Y.; LUOB, Q.; SUNC, M.; CORKE, H. Antioxidant activity and phenolic compounds of 112 traditional Chinese medicinal plants associated with anti-cancer. Life Sci., v.74, n.17, p.2157-2184, 2004.

DANIEL, M.T.; FLANDRIN, G.; LE’VEUNE, F.; LISO, P.; CORTHOLARY, P.F. Les estérases spécifiques monocytaires: utilisacion dans la classificación de leucemies agués. Nov. Rev. Franc. Hemat., v.11, p.233-240, 1971.

DHANABAL, S.P.; JERALD, E.E.; KUMAR, E.P.; SURES, B. Hypoglycaemic effect of alcoholic extract of various species of Passiflora on alloxan-induced diabetes mellitus in albino rats. Niger. J. Nat. Prod. Med., v.8, p.19-21, 2004. 
DHAWAN, K.; DHAWAN, S.; SHARMA, A. Passiflora: a review update. J. Ethnopharmacol., v.94, n.1, p.1-23, 2004.

DOYAMA, J.T.; RODRIGUES, H.G.; NOVELLI, E.L.; CEREDA, E.; VILEGAS, W. Chemical investigation and effects of the tea of Passiflora alata on biochemical parameters in rats. J. Ethnopharmacol., v.96, n.3, p.371374, 2005.

DUDONNÉ, S.; VITRAC, X.; COUTIERE, P.; WOILLEZ, M.; MÉRILLON, J. Comparative study of antioxidant properties and total phenolic content of 30 plant extracts of industrial interest using DPPH, ABTS, FRAP, SOD, and ORAC assays. J. Agric. Food Chem., v.57, n.5, p.17681774, 2009.

EDEAS, M.; ATTAF, D.; MAILFERT, A.; NASU, M.; JOUBET, R. Maillard reaction, mitochondria and oxidative stress: potential role of antioxidants. Pathol. Biol., v.58, n.3, p.220-225, 2010.

ETUK, E.U. Animals models for studying diabetes mellitus. Agric. Biol. J. N. Am., v.1, n.2, p.130-134, 2010.

FERREIRA, C.S.; ARAÚJO, T.H.; ÂNGELO, M.L.; PENNACCHI, P.C.; OKADA, S.S.; PAULA, F.B.A.; MIGLIORINI, S.; RODRIGUES, M.R. Neutrophil dysfunction induced by hyperglycaemia: modulation of myeloperoxidase activity. Cell Biochem. Funct., v.30, n.7, p.604-610, 2012.

GEERLINGS, S.E.; HOEPELMAN, A.I.M. Immune dysfunction in patients with diabetes mellitus (DM). FEMS Immunol. Med. Microbiol., v.26, n.3-4, p.259-265, 1999.

JAMIR, T.T.; SHARMA, H.K.; DOLUI, A.K. Folklore medicinal plants of Nagaland. Fitoterapia, v.70, n.4, p.395401, 1999.

KOH, G.C.K.W.; PEACOCK, S.J.; VAN DER POLL, S.J.; WIERSINGA, W.J. The impact of diabetes on the pathogenesis of sepsis. Eur. J. Clin. Microbiol. Infect. Dis., v.31, n.4, p.379-388, 2012.

LI, H.W.; ZHOU, P.; YANG, Q.Q.; SHEN, Y.; DENG, J.; LI, L. Comparative studies on anxiolytic activities and flavonoid compositions of Passiflora edulis 'edulis' and Passiflora edulis 'flavicarpa'. J. Ethnopharmacol., v.133, n.3, p.10851090, 2011.
MCNELIS, J.C.; OLEFSKY, J.M. Macrophages, immunity, and metabolic disease. Immunity, v.41, n.1, p.36-47, 2014.

MOLYNEUX, P. The use of the stable free radical diphenylpicrylhydrazyl (DPPH) for estimating antioxidant activity. Songklanakarin J. Sci. Technol., v.26, n.2, p.211219, 2004.

OLIVEIRA, A.C.; VALENTIM, I.B.; SILVA, C.A.; BECHARA, E.J.H.; BARROS, M.P.; MANO, C.M.; GOULART, M.O.F. Total phenolic content and free radical scavenging activities of methanolic extract powders of tropical fruit residues. Food Chem., v.115, n.2, p.469-475, 2009.

PANNEERSELVAM, S.; GOVINDASAMY, S. Sodium molybdate improves the phagocytic function in alloxaninduced diabetic rats. Chem. Biol. Interact., v.145, n.2, p.159-163, 2003.

RODRIGO, R.; MIRANDA, A.; VERGARA, L. Modulation of endogenous antioxidant system by wine polyphenols in human disease. Clin. Chim. Acta., v.412, n.5-6, p.410-424, 2011.

RONDEAU, P.; BOUNDON, E. The glycation of albumin: Structural and functional impacts. Biochimie, v.93, n.4, p.645-658, 2011.

RUDNICKI, M.; OLIVEIRA, M.R.; PEREIRA, T.V.; REGINATTO, F.H.; DAL-PIZZOL, F.; MOREIRA, J.C.F. Antioxidant and anti-glycation properties of Passiflora alata and Passiflora edulis extracts. Food Chem., v.100, n.2, p.719-724, 2007.

SHAW, J.E.; SICREE, R.A.; ZIMMET, P.Z. Diabetes atlas. Global estimates of the prevalence of diabetes for 2010 and 2030. Diabetes Res. Clin. Pract., v.87, n.1, p.4-14, 2010.

SCHLEICHER, E.D.; BIERHAUS, A.; HARING, H.U.; NAWROTH, P.P.; LEHMANN, R. Chemistry and pathobiology of advanced glycation end products. Contrib. Nephrol., v.131, p.1-9, 2001.

SINGLETON, V.L.; ORTHOFER, R.; LAMUNELA, R.M. Analysis of total phenols and other oxidation substrates by means of Folin-Ciocalteau reagent. Meth. Enzymol., v.299, p.152-178, 1999.

SLAUCH, J.M. How does the oxidative burst of macrophages kill bacteria? Mol. Microbiol., v.80, n.3, p.580-583, 2011. 
SOUZA, L.F.; BARRETO, F.; DA SILVA, E.G.; ANDRADES, M.E.; GUIMARÃES, E.L.; BEHRGA, M.J.C.; BERNARD, E.A. Regulation of LPS stimulated ROS production in peritoneal macrophages from alloxan-induced diabetic rats: Involvement of high glucose and PPAR $\gamma$. Life Sci., v.81, n.2, p.153-159, 2007.

SOUZA, J.N.; SILVA, E.; LOIR, A.; REES, J.; ROGEZ, H.; LARONDELLE, Y. Antioxidant capacity of four polyphenol-rich Amazonian plant extracts: A correlation study using chemical and biological in vitro assays. Food Chem., v.106, n.1, p.331-339, 2008.

VILIM, V.; WILHELM, J. What do we measure by a luminoldependent chemiluminescence of phagocytes? Free Radic. Biol. Med., v.6, n.6, p.623-629, 1999.
WILLIANS, N.L.; MORRIS, J.L.; RUSH, C.; GOVAN, B.L.; KETHEESAN, N. Impact of streptozotocin-induced diabetes on functional responses of dendritic cells and macrophages towards Burkholderia pseudomallei. FEMS Immunol. Med. Microbiol., v.61, n.2, p.218-227, 2011.

WOOTTON-BEARD, P.C.; MORAN, A.; RYAN, L. Stability of the total antioxidant capacity and total polyphenol content of 23 commercially available vegetable juices before and after in vitro digestion measured by FRAP, DPPH, ABTS and Folin-Ciocalteu methods. Food Res. Inter., v.44, n.1, p.217-224, 2011.

ZILIN, S.; NAIFENG, L.; BICHENG, L.; JIPING, W. The determination of AGE peptides by flow injection assay, a practical marker of diabetic nephropathy. Clin. Chim. Acta., v.313, n.1-2, p.69-75, 2001.

Received for publication on 25 October 2014 Accepted for publication on 18 June 2015 